\title{
Islamic Education Values in Ziarah Kubur Tradition of Javanese People
}

\author{
Matrokhim \\ LAIN Salatiga \\ rokbim125@gmail.com
}

\begin{abstract}
This study discusses the values of Islamic education in the ziarah kubur tradition of Javanese people in Ngemplak Kumpulrejo, District Argomulyo, and Salatiga city. The focus studied in this research is how the history of ziarah kubur in Islamic teachings, what are the rituals found in the ziarah kubur in Ngemplak Kumpulrejo, Islamic education values of any kind found in the ziarah kubur in Ngemplak Kumpulrejo. This qualitative research uses field research methods, where the researchers becomes very important as researchers act directly as direct instruments and as a data collector of observation results and actively involved in the research. From the research conducted the following research results: Islamic educational values contained in the ziarah kubur tradition in Kumpulrejo, is that there is a mixture of Islamic traditions and Javanese culture that is integrated into a tradition that goes hand-over beautifully without eliminating the significance of the value of Islamic traditions and Javanese culture. And from the procession of the ziarah kubur tradition of Javanese people, especially in Ngemplak Kumpulrejo, contain the values of Islamic education such as faith, Birrul Walidain, the value of education so that people always submit to the world and the value of social education. And then is expected to be taken from the procession of ziarah kubur traditions.
\end{abstract}

Keywords: zakat; fundraising; strategy; challenges; digital era.

\section{Abstrak}

Penelitian ini membahas tentang Nilai-nilai Pendidikan Islam dalam Tradisi Ziarah Kubur Masyarakat Jawa di Ngemplak Kumpulrejo, Kecamatan Argomulyo, Kota Salatiga. fokus yang dikaji dalam penelitian ini adalah bagaimana sejarah ziarah kubur dalam ajaran agama Islam, ritual apa saja yang terdapat dalam ziarah kubur di Ngemplak Kumpulrejo, nilainilai pendidikan Islam apa saja yang terdapat dalam ziarah kubur di Ngemplak Kumpulrejo. Penelitian kualitatif ini menggunakan metode 
field reasearch , dimana kehadiran peneliti menjadi sangat penting karena peneliti bertindak langsung sebagai instrumen langsung dan sebagai pengumpul data dari hasil observasi serta terlibat aktif dalam penelitian. data yang berbentuk kata-kata diambil dari informan atau responden pada waktu mereka diwawancarai. Dari penelitian yang dilaksanakan diperoleh hasil penelitian sebagai berikut : Nilai-nilai pendidikan Islam yang terkandung dalam tradisi ziarah kubur di Ngemplak Kumpulrejo, adalah bahwa adanya percampuran antara tradisi Islam dan Budaya Jawa yang menyatu menjadi sebuah tradisi yang berjalan beriringan dengan sangat indah tanpa menghilangkan makna dari nilai tradisi Islam dan budaya Jawa. Dan dari prosesi pelaksanaan tradisi ziarah kubur masyarakat Jawa khususnya di Ngemplak Kumpulrejo mengandung nilai-nilai pendidikan Islam berupa: nilai pendidikan keimanan, nilai pendidikan birrul walidain, nilai pendidikan agar manusia senantiasa berzuhud kepada dunia dan nilai pendidikan sosial. Dan diharapkan dapat diambil suri tauladan dari prosesi pelaksanaan tradisi ziarah kubur tersebut.

Kata Kunci: Nilai-nilai Pendidikan Islam, Tradisi Ziarah Kubur, masyarakat jawa.

\section{INTRODUCTION}

Each ethnic group has its habits, traditions, customs, and cultures affecting each other with fluctuation of growth and development. They can live alongside harmony and tolerance with different civilizations. We can see the understanding of Kejawen that cannot be separated from the life of Javanese people. This understanding is often identified with mysticism. According to the Indonesian Dictionary or KBBI "Mysticism is a teaching that states there are things that are unreachable by human mind that is supernatural." As for the word mysticism does not entirely contain the correct assumption, but it is true the world of Kejawen cannot be released from the mystical world and so is the mystical that cannot be removed from the understanding of Kejawen.

Before the coming of Hindu and Buddhist teachings in Java, the Javanese had known and convinced a belief that was syncretism, namely animism and dynamism. This is where the roots of the belief problem of Javanese people to date where the belief in animism and dynamism is still in use, while the Hindu and Buddhist religions are only used as dyes only 
from the religious procession they do. And the inclusion of the religion of revelation such as Islam is also not deadly belief will understand this. It continues to run the tide following the development and changing times. This is realized by the belief in the spirits who control the places in this part of the Earth.

Before the coming of Hindu and Buddhist teachings in Java, the Javanese had known and convinced a belief that was syncretism, namely animism and dynamism. This is where the roots of the belief problem of Javanese people to date where the belief in animism and dynamism is still in use, while the Hindu and Buddhist religions are only used as dyes only from the religious procession they do. And the inclusion of the religion of revelation such as Islam is also not deadly belief will understand this. It continues to run the tide following the development and changing times.

Along with the inclusion of Islamic religion in the century $\mathrm{XV}$ precisely gave the pattern of growth of the Kejawen, which was originally derived and handed down to posterity, thus creating a new cultural phenomenon that is a mixture of Kejawen understanding with Islamic religious teachings. It can be modeled after the growing and growing art of the puppet culture used by Walisongo as a medium of Islamic propagation. So, "Wayang is indeed the most important performing arts to be a means of entertainment that is as good as the socialize values of Javanese traditions and culture that are considered sublime. In Wayang puppet show is expressed the delicate feudal manners that apply in Kraton "(Simuh, 1999:119). Thus the Wali are a propagation of Islamic religion that preach through the arts, in addition to the preferred Javanese people as entertainment in the old days, they also got the meaning conveyed by the Wali through the Wayang show. There is still a belief in the spirits who control the places in this part of the Earth.

In Islamic religious tradition, the concept of the term ziarah kubur is part of a religious ritual. The purpose of the ziarah kubur is to visit, to see the silent grave and the heap on it will move the hearts and souls of men to prepare for death. Moreover, those who perform ziarah kubur can take lessons from the behavior and the example of the predecessors 
JNUS: Journal of Nahdlatul Ulama Studies, Vol. 1, No. 2, Juli 2020: 131-161

of the people visited. The ziarah kubur is expected to be a reminder to Allah SWT.

In Javanese society, the tradition of ziarah kubur is the inner strengthening of fellow human beings and as well as local wisdom. The tradition of ziarah kubur in Javanese community itself has existed since before the advent of Islamic religion to Java land. Anciently they performed a ziarah kubur to the grave to make inner contact with arwah leluhur or their families who had died. In performing the ziarah kubur, they carried the device in the form of flowers and frankincense as offerings for the dead spirits.

When Islam enters, the ziarah kubur tradition with all the devices is continuing. Then by the Wali, infiltrated Islamic teachings and began to be eliminated values that contradict Islamic teachings in the tradition of ziarah kubur (Abdul Maman, 2006:198).

From the explanation above arises a desire from researchers to know the intent, the purpose and know the values of Islamic education contained in the procession of ziarah kubur that has been traditions especially in the community Ngemplak Kumpulrejo District Argomulyo, City of Salatiga. Where local people consider that the ziarah kubur procession that they do aims to carry out the teachings of Islam and to preserve the traditions contained in the belief of Javanese society. Moreover, the ziarah kubur procession contains the values of Islamic education.

\section{METHODOLOGY}

In solving the problem in this study, the authors used the document in the form of books, and the literature to be studied comprehensively, especially those relating to Islamic educational values and ziarah kubur traditions. In conducting research, the approach used is qualitative research. The strategy that is used to address research issues is a grounded strategy that the authors study carefully on the documents and findings in the field.

In this research, authors act as a data collector and as an active instrument in the effort to collect data in the field, whereas other data 
Islamic Education Values in Ziarah Kubur Tradition ..... (Matrokhim)

collection instruments other than human beings are various tools and other documents that can be used to support the validity of the research, but function as supporting instruments.

The type of data collected in the study is qualitative data which is the form of words, and actions, in which case the data type is divided into words and actions, written data sources, photographs, and statistics. The rest is additional data such as documents and others (Lexy J. Moeloeng, 2009:157; quoted from Lofland and Lofland, 1984:47). The document referred to in this study is a document containing the values of Islamic education in the tradition of grave pilgrimage.

\section{RESULT AND DISCUSSION}

\section{Islamic Education}

\section{Definition of Islamic Education}

Education is a process of cultural transformation that is interpreted as a cultural inheritance activity from one generation to another. These cultural values undergo the transformation process from the old generation to the younger generation. Education is also interpreted as a systematic and systematically directed activity to the creation of the students ' personality. Systematic because the process of education takes place through continuous and systematic stages because it takes place in all conditions of the condition, in the entire environment that fills each other (home environment, school, and community).

Islamic education in Arabic is called Tarbiyatul Islamiyah which means the right and obligation in every human being who wants to save himself in the world and the hereafter. According to Fuad Hasan (2003:11-12), "education means scribing. To provide a conscious and deliberate relief to a child (immature) in its growth towards maturity in the sense of being able to stand alone and responsibly." Education also leads to the delivery of information about new things to a person and the transformation process will be formed in science so that it will make the human being insightful. So Islamic education is to give information and 
JNUS: Journal of Nahdlatul Ulama Studies, Vol. 1, No. 2, Juli 2020: 131-161

teach a man to maturity so that he can be responsible for himself according to Islamic teachings.

\section{Objectives of Islamic Education}

An education expert named Kohsntam mentions that the purpose of education is to assist a person in the process of self-learning to achieve the ultimate inner tranquility, without disturbing or without burdening others (Kartini Kartono, 1992:219). But in general, the educational objectives contain a picture of good, sublime, appropriate, true, and wonderful values for life. Education has two functions that give direction to all educational activities and something that want to be achieved by all educational activities.

Islamic education to fulfill its function in dealing with social realities must walk along with non-religious education programs, both in public schools and in religious schools. Two reasons are underlying this principle. The first fundamental reason is that every education program as long as the program deserves to be called an educational program is ultimately aimed at forming human beings, people of noble morality. Secondly, pragmatic reasons are the ability to assess the normative social reality and the ability to think of ways that can be pursued to improve a situation, will be more easily built when a kind of interaction between non-religious education, especially in public schools, will only be an ornament of a mere curriculum (Kautsar Azhari Noer, 2005:229).

So, Islamic education aims to make human beings noble, and then have moral values such as affection, love, please help, tolerance, consideration, respect and maintain harmony among others.

\section{History of Islamic Traditions in Java}

The Islamic religion is spread by the Prophet Muhammad SAW at first only in the limited circles, namely the family and the closest companions. In a relatively short time, Islam grew rapidly. After the death of the Prophet Muhammad SAW, Islam was described by four friends who were famous for the degree Khulafaur Rasyidin, namely Abu Bakar, Umar ibn 
Khattab, Usman ibn Affan, and Ali ibn Abi Talib. Until eventually Islam came into the land of Java.

Broadcasting Islam is a duty for every Muslim, as it is ordered by Islam. Every Muslim has to broadcast religion, whether that knowledge of religion is a little more than for those who have more knowledge of religion to people who do not know it. This is because the truth contained in every Muslim breast will not be silent unless the truth is manifested in thought, word, and deed. And it will not be satisfied until he conveys that truth to everyone so that what he believes can be accepted as truth by other members of the community.

Islam is an important element of the Javanese people's identity. Islamic teachings and culture flow heavily from Arabia and the Middle East giving a very strong color to Javanese culture.

Java Island is always open to anyone who enters. Javanese people are known to be friendly since long ago and ready to cooperate with anyone. Including when traders, Ulama', the pointed nose, and the reddish-white skinned came to the Javanese furnace. They are merchants of the Middle East land. Their arrival brought a new history for the Javanese people, the history of the Islamic religion that entered the island of Java.

Until now it is not known exactly about the entry of Islam to Java land. According to Djamal, quoted by Budiono (2010:10), there are 3 opinions on when Islam is entering and where it comes from.

First, Islam has entered the land of Java since the 9th $M$ through the north Coast of Java Island based on the discovery of one's tomb in Leran, Gresik named Fatimah Binti Maimun who died in 1082. This view invites objections to various circles because it is suspected that the tombstone was brought into Java after the year it was listed. There is an opinion that the buried there is not Javanese, but the possibility is an outside people who travel to Java and died there. Javanese people who died using gravestones originating from outside Java so it is possible that the gravestone in Leran was also brought from outside Java after the year on the gravestone. 
Secondly, Islam has been in Java since the 14th $\mathrm{M}$ based on the gravestone found in Trowulan. The gravestone showed the number 1368 $\mathrm{M}$ which gave the inscription that in that year there were Javanese people from among the kingdoms who embraced Islam for the protection of the kingdom. This fact gives a clue that the entry of Islam in the years before it has certainly been through the coastal area which then to the inland region.

Thirdly, Islam is already in Java in the 15th $\mathrm{M}$ based on the gravestone from the tomb of Maulana Malik Ibrahim who died in $1419 \mathrm{M}$. Some views state that he was a wealthy Persian man engaged in the spice trade. Another view stated that he was one of the nine mayors who considered the spread of Islam on the island of Java.

From some opinions, it can be that Islam began to enter Java, at least, since the beginning of the 10th century, as seen on the gravestone found in Learn, Gresik. Although at that time few Javanese people entered the religion of Islam and it was limited to the people on the northern coast of Java. It is even possible that adhered to Islam in Java at that time only the entrants who settled in the area, not the local population (indigenous people) who at that time still embrace animism and dynamism and Hindu-Buddhist religion

The spread of Islam, according to Woodward, is the process of the continuity of the spread of religion in the archipelago and its encounter with the internal conditions of the community passed, (quoted by Humaedi, 2008:12). In Indonesia, especially in Java, the process is spread according to Mansur (2004:112), through several lines such as trade, marriage channels, Sufism, education, arts, and politics.

For the next three centuries, the teachings of Islam that do not know the caste or social class slowly but surely increasingly enthused by the indigenous people in the port towns of Java island. Finally, the Islamic religion can develop rapidly on the coast of Java since the beginning of the 14 th $\mathrm{M}$.

Islamic religion can be easily accepted by society because of its teachings that do not know the caste to encourage the bribery of the caste 
system in Hindu society and Islamic religion with its very strong legal awareness of the reason Islam can be rapidly spread in Java, Nur Cholish, 1997:17).

The inclusion of Islam to Java was carried out by merchants from Arabia who ran a slam cruise, combing the coast from Jeddah through the Persian Teluik to Gujarat on the west coast of India (Selamet Muljana, 2007:146-147). Although not an Arab person who entered Indonesia with a purpose is to teach Islam (Steenbrink, 1984:133). By itself, only merchants on the Persian coast and the west coast of India are directly related to Arab merchants, who have embraced Islam. Gujarat was the center of the meeting of Arab merchants, Persians, Indians, and merchants from Malacca and became the center of Islamic Religious Life and the base of its spread in Southeast Asia.

The spread of Islam in Java is not related to Walisongo. According to the Indonesian Dictionary (1989:1007), the Guardian means a holy or sacred person and is well-known to be plundered by Javanese soil. Meanwhile, according to Mohamad Ngajenan (1990:181), Wali is a person who does a good and noble person in the land of Java. Because the era of Walisongo is the era of the end of Hindu-Buddhist domination in Javanese culture to be replaced with Islamic culture or traditions (Budiono, 2010:17). Walisongo is a symbol of spreading Islam in Indonesia, especially in Java. The role of Walisongo also plays a major role in establishing the Islamic kingdom in Java Island.

One of the ways that the Wali of spreading Islam in the island of Java by preaching. This spread is done by visiting the community as a Da'wah object using socio-cultural methods. This method uses the form of acculturation, which is using the local culture by entering the teachings of Islam in it. In addition, these guardians established Pesantren-Pesantren as a means of Islamic education.

Islamization in the land of Java can be said largely because of the results of Da'wah and struggle Walisongo. It is impossible that Walisongo will succeed in their preaching if they are not virtuous, subtle, gentle and friendly and caring and compassionate to the people. 
JNUS: Journal of Nahdlatul Ulama Studies, Vol. 1, No. 2, Juli 2020: 131-161

In carrying out the task of embedding Islamic values, it is said that Walisongo preached according to the law that was determined by Allah SWT. They brought the Javanese community to the teachings of Islam according to their needs. Walisongo is considered sacred because it divides the grace and blessings that radiate from their own. The authority and power of the guardians can bring back the servants to the policy cage so that they are inevitable from the anger of man and the wrath of God in the hereafter.

Starting from the first Wali, namely Maulana Malik Ibrahim or Makmud Ibrahim As-Samarkandy. He was born in Samarkand, Central Asia in the early half of the 14th M Maulana Malik Ibrahim sometimes also called Syeh Maghribi. Some people even call it Kakek bantal. He was the son of Maulana Jumadil Qubra, a Persian scholar. Maulana Jumadil Qubra is believed to be the descendant of Muhammad SAW from his tweet Zaynal ' Abidin bin Hasan bin ' Ali (Widji Saksono, 1995:24). Maulana Malik Ibrahim once preached in Campa in present-day Kambodja in $1379 \mathrm{M}$ and after successfully Islamized King Kiyan of the Campa he was taken in his son-in-law and married the king's daughter who gave him two sons (Widji Saksono, 1995:24). They are Raden Rahmat (Sunam Ampel) and Sayid Ali Murtadha or Raden Santri. Feel enough to live a da'wah mission in the country. In 1329 M, Maulana Malik Ibrahim moved to the island of Java leaving his family. The first area in the country was Learn village, Gresik, which is still in the power of Majapahit kingdom. His first activity at the time was to trade by opening a stall. Stall provides necessities at a cheap price. Besides, Maulana Malik Ibrahim also provided himself to treat the public for free. Grandpa Pillow also teaches new ways to grow crops. He embraced the lower community (caste set aside during the Hindu-Buddhist period). So perfect the first mission, which is looking for a place in the hearts of surrounding society. After finishing building the cottage as a means of studying Islamic religion in Leran, Gresik, in 1419 Maulana Malik Ibrahim died. His grave is still in Leran, Gresik, and East Java. 
Patah, the son of Prabu Brawijaya V the king of Majapahit, to become the Sultan of Demak in 1475 A.D. in Ampel, the area which was awarded by the King of Majapahit (Widji Saksono, 1995:28), he built and developed boarding school. At first, he embraced the surrounding community. In the middle of the 15th century, the boarding school became a very influential education center in the archipelago area even foreign. Among its centers are Sunan Giri and Raden Patah. The Santrinya was then spread to preach to various corners of Java and Madura. He introduced the term "Mo Limo" (MoH Maen, $\mathrm{MoH}$ Ngombe, $\mathrm{MoH}$ maling, MoH madat, MoH Madon). Namely the call to " Moh maen, moh ngombe, moh maling, moh madat, moh madon." Sunan Ampel is thought to have died in M. In Demak and was buried next to the Ampel Mosque in Surabaya.

The Fourth is Sunan Bonang. Sunan Bonang was the son of Sunan Ampel, which means grandson of Maulana Malik Ibrahim. His childhood name was Raden Makdum Ibrahim (Widji Saksono, 1995:29). Da'wah by Sunan Bonang is conveyed popularly through the art media that is liked by society. In this case, Sunan Bonang shoulders with his disciple, Sunan Kalijaga. Sunan Bonang also changed the gamelan which is then thick with Hindu nuance, by giving a new nuance. He was the creator of Javanese gamelan as now, by adding the instrument Bonang. In the puppet scene, Sunan Bonang is the mastermind who whiskers his audience. His Passion is changing the Lakon and incorporating Islamic interpretations into it.

The fifth is Sunan Drajat, who in his childhood had the name of Raden Qasim. He was the son of Sunan Ampel meaning he was the brother of Sunan Bonang. The title of Raden Syaifuddin was born in 1470 M. In the teaching of Tauhid and Aqidah, he imitated the way his father was done directly and did not approach the local culture. Nevertheless, the way of delivery adapted the artistic way of Sunan Muria. In the boarding school, Sunan Drajat is also known as a humble person who likes to help. In his book lodge, he kept a lot of orphans and poor children. 
The sixth is Sunan Gunung Jati or Syarif Hidayatullah is thought to have been born in $1448 \mathrm{M}$. Following the establishment of Bintaro Sultanate of Demak, and on the blessing of the other scholars, he founded the Sultanate of Cirebon, also known as Pakugwati Sultanate. Sunan Gunung Jati used his influence as the son of King Pajajaran to spread Islam. In preaching, he approached the community by building the infrastructure in the form of roads linking between regions. With his son, Maulana Hasanuddin, Sunan Gunung Jati also traveled to Banten. Local ruler, Pucuk General gave a voluntary mastery of the Banten region which later became the forerunner of the Banten Sultanate. Sunan Gunung Jati died at 120 years old in Cirebon.

The seventh is Sunan Muria, the son of Sunan Kalijaga. His inbetween style imitates his father's style, but unlike his father, he prefers to live in remote areas and far from the city center to spread Islam. Associating with the commoners to teach farming, trading, and farming skills is his favorite. Sunan Muria was often used as an intermediary in the internal conflict in the Sultanate of Demak (1518-1530 A.D.). He is known as a person who can solve various problems. The solution can also be accepted by various parties. Sunan Muria preached from Jepara, Tayu, Juana to around Kudus and Pati. One of his results through art was the song Sinom and Kinanti.

The eighth is Sunan Kudus, who has a nickname Ja'far Shadiq. He studied at Sunan Kalijaga. Then he traveled to various barren places in central Java such as Sragen, Simo to Gunung Kidul. He also imitates the style of Sunan Kalijaga, which is very tolerant of local culture. The delivery is even smoother. That is why the guardians who have difficulty finding the prosecution to Kudus are the majority of the community adhered to the Hindu-Buddhist religion. The way of being holy is approaching the holy people is by utilizing Hindu and Buddhist symbols. It was seen from the architecture of Kudus mosque. The shape of the tower, gate, and shower ablution symbolizing are eight Buddhist roads. For that, he accidentally laid the cow named Kebo Gumarang in the yard of the mosque. The Hindu people who glorify cows become sympathized 
especially after they have listened to the explanation of Sunan Kudus about Sura Al-Baqarah which means cow. Until now some of the traditional holy people still refused to slaughter cows. Sunan Kudus also changed the story about the Tauhid where the story was serialized so that the people were interested to follow it. That is how the Sunan Kudus is done to bind his people.

The ninth is Sunan Kalijaga.) He was born in $1450 \mathrm{M}$ and had a small name of Raden Said (Budiono, 2010:175). In preaching he chose culture and arts as a means to preach. He was very tolerant of local culture because he argued that society would move away if they were attacked. Then they must be approached gradually, by following the influence while influencing. Sunan Kalijaga believes that if Islam is already understood, the old habits will be lost. Thus the teachings of Sunan Kalijaga impressed the syncretic in introducing Islam. He used the art of carving, puppet, gamelan and sound art as a means of da'wah. He is the creator of Takwa clothes, Sekaten celebrations, Grebeg Maulud, Layang Kalimasada, Wayang plays Petruk so king. The city center emblem of Keraton, the square with two Banyan and mosque is believed as the work of Sunan Kalijaga (Department of Education and Culture Prov. Jateng, 2007:31). The method of Da'wah was effective because many dukes who finally embraced Islam in the time of Sunan Kalijaga.

According to Shaykh Mahfudz (quoted by Widji Saksono, 1995:213) said that the condition to be a da'wah must have two references, namely religious sciences that are based on the venerable and moral morality, and the sciences that include the Social sciences and Islamic sciences. And it is in the Walisongo who have great service in the spread of Islamic Aga in Java.

In particular, Walisongo in provide multilevel instruction to the community. In their practice they are faced with Javanese people who are still the thick influence of Hindu-budonly, Walisongo not at once directly flooded with the same with Islam in the form of very foreign archives for them. Walisongo first gives Islamic, Hindu and Buddhist forms in the form of Kejawen. About spells for example, while simply directing intent 
by adding the initial use of Bismillah concludes with Lailahaillallah and other times plus a more pure trail forward. Meanwhile, the ritual of the offerings was replaced with the term alms from the word shadaqah, or the blessings and offerings that complement it are called the blessing of the word Barakah (Widji Saksono, 1995:212).

\section{Ziarah Kubur}

\section{Definition, history and goal of Ziarah Kubur}

According to Afnan Chanafi and Ma'ruf Asrori (2007:230), the word "ziarah" in the language means to look, so the ziarah kubur means to see the grave. According to Islamic sharia, the pilgrimage of the grave is not only to see the grave, not just to know and understand where it is buried, or to know the state of the grave, but the coming of one to the grave is intending to pray for someone who has passed away and sent a reward for him on the recitation of the verses of the Qur'an and kalimat Thayyibah, such as Tahlil, Tahmid, Tasbih, Shalawat, and others

In the early days of the prophet SAW that Islam had forbidden the Muslims to perform the ziarah kubur because the prophet was worried about the occurrence and worship of the grave. After all, at that time the faith of the Prophet SAW companions is still weak and still needs guidance from the Prophet Muhammad SAW. In the tradition of Muslim on the island of Java ziarah kubur is one of the traditions that still run until now; it is also not separated from the influence of Hindu-Buddhist religion. In the period Hindu-Buddhist king regarded as the title of God then anything related to the king is considered sacred including also the grave of the Kings.

After Islam entered the island of Java and was spread by Walisongo, ziarah kubur has been modified by them so that there is a mixture of pilgrimage tradition of the grave which is still thick with Hindu-Buddhist nuance by entering by Islamic tradition by eliminating things that smell shirk and replace with Islamic religious teaching, so that the pilgrimage of the grave at this time is acculturation between Javanese culture and Islamic tradition. 
Like the ziarah kubur phenomenon that is still done in Keraton Yogyakarta when the coronation of Sri Sultan Kamengku Buwono X became Sultan on 7 March 1989 M done in two tombs namely Kotagede tomb and the tomb of Imogiri (BJSSHB drafting Team, 1995:29). The ceremony was done by first performing Tahlilan with the intention to pray for the spirits of the fathers so that his sin was forgiven, and all charity deeds were received on the side of the Almighty God. The burial of the tomb is done with the aim that all the ancestors who sumare in the tomb of Kotagede gave a blessing to Sri Sultan Hamengku Buwono X who has been crowned king. In addition, the activity is also a hope that the new Sultan will always be able to emulate the ancestors who have a noble person. After completion of Tahlilan Sri Sultan Hamengku Buwono X and the group sprinkled flowers above the tomb of the ancestors.

Among ordinary people, already a common sight on Thursday afternoon or Friday morning they familiarize themselves with the pilgrimage to the cemetery because those times were the leisure time for the holidays on Friday. If it is in the grave of Kyai Pesantren or family ziarah kubur, if at home then the tomb of the family is visit. The ritual usually begins with clearing the grave environment from the garbage of the leaves, or sprinkled flowers above the tomb. Then after that new reading Qur'an, that or Yasin letter. There is no limit that binding is all done with sincerity and then end by reading the prayer, namely pray for yourself, the mothers and fathers, the family, and pray for the person whose grave is visited and pray for the Muslim to Allah SWT, not to others (Munawar, 2008:184).

In addition to the main purpose to pray for the people who are visited to get forgiveness of Allah SWT and get rewarded, pilgrimage grave also contains the purpose and wisdom that is beneficial for those who perform the pilgrimage. The first goal is to remind someone of the hereafter. The future in the afterlife of mankind will be awakened (quickened) again by Allah SWT to receive justice and a reply to the charity of human deeds while living in the world, be it good charity that will be answered with neither reward, nor bad nature that will be replied 
with torment in hell, all will get a fair reply. The second is to be able to do the world. Zuhud to the world is to leave the world to worship Allah SW'T (Afnan and Ma'ruf, 2006:237). People should not be captivated by his heart and mind by the wiles of the world but he can distribute the property he obtained with a path that is lawful to be righteous deeds that are made by Allah SWT do Sedekah, Infaq, and Zakat. Because of our charity, Infaq and a decadent is our essential and everlasting treasure, which we will be able to take advantage of later in the Hereafter, being a treasure other than that only a deposit and we will not take it when the death invites us. The third is to be taken by the death of the ritual, we must prepare early in the provision that we will carry when the death invites, not the treasures that we carry, but righteous charities that will be able to help someone in the hereafter.

\section{Wisdom and boundaries in Ziarah Kubur}

Ziarah kubur is Sunnah, as is narrated by Ahmad, Muslim, and Ashabussunnah from Abdullah ibn Buraidah, who received from his father that the Prophet Muhammad said:

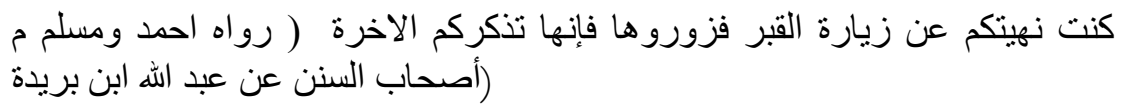

Meaning: "In the past I forbade visiting the graves, as for now, make pilgrimages there, because that will remind you of the last day"(Narrated by Ahmad, Muslim and Ashabussunnah)

Ziarah kubur is Sunnah, as is narrated by Ahmad, Muslim, and Ashabussunnah from Abdullah ibn Buraidah, who received from his father that the Prophet Muhammad SAW this hadeeth, the ziarah kubur is permissible for both men and women. However, what about the hadith of the Prophet that expressly states the prohibition of the ziarah kubur as follows:

$$
\text { (عن ابي هريرة أن رسول اله صلى اله عليه وسلم لعن زورات القبور (رواه احمد }
$$


Islamic Education Values in Ziarah Kubur Tradition ..... (Matrokhim)

Meaning: "From Abu Hurairah RA that actually Rasulullah SAW cursed women who pilgrimage to the grave." (Narrated by Ahmad).

Addressing this hadits the scholars stated that the prohibition was revoked as a pilgrimage for both men and women. In the Book of Sunan Al-Tirmidhi is mentioned:

$$
\begin{aligned}
& \text { وقد رأى بعض أهل العلم أن هذا كان قبل أن يرخص النبي صلى الله عليه وسلم في }
\end{aligned}
$$

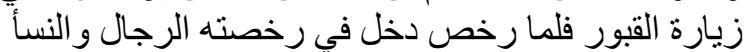

Meaning: "Some scholars say that the hadith was spoken before Prophet Muhammad SAW allowed him to perform the grave pilgrimage. After Rasulullah SAW allowed it, men and women were covered in this ability. " (Sunan Al-Tirmidhi, p. 976. Quoted from Afnan and Ma'ruf, 2007: 231).

Previously, the Prophet Muhammad SAW never banned Muslims to perform the grave pilgrimage. The prohibition is because at that time the faith condition of Muslims still very weak so that they feared they will fall into the abyss of error. But after the faith of Muslims at that time was strong, then the Prophet Muhammad SAW allowed his people to do the pilgrimage of the grave.

In the implementation, there are things that makruh to be done when performing the grave pilgrimage. Quoted from fimadanicom (accessed on Thursday, 20 November 2014. At 12.56), there is a matter of makruh when performing grave pilgrimage. The first is according to Madzhab Maliki stating that the law Makruh eats, drinks laughs, and many speak, including also reading the Qur'an in a loud voice. It is not appropriate for someone in the cemetery. The second is that the ruling is to smell the chest made over the tomb, or kiss the tomb, or kiss the door when entering a ziarah to someone's tomb. The third is that the ruling is to specialize in certain days to perform the grave pilgrimage, because ziarah kubur can be done at any time. The fourth is the ruling Makruh to pray exactly above the grave and facing the grave without a barrier wall, excepted for people who want to pray for the body but do not have a chance to save when a person has not been buried. The fifth is that a 
person's law is urinating and defacation on the tomb. The sixth is the ruling of praying; asking for protection, asking for help to the inhabitants of the tomb (the grave) is unlawful and is shirk. The seventh is that the law makruh put a candle or a lamp on the tomb of a person because it is the ordinance of the Pilgrimage of the people of the book and the Majusi. The eighth is that the ruling is to give the offerings in any form above one's grave

\section{The Ordinance of Pilgrimage}

The ordinances in the pilgrimage according to Afnan and Ma'ruf (2007:231-235) are with Wudoo' before heading to the tomb for pilgrimage. And then until the tomb shall give greetings and pray for him (Yusuf Chudlori, 2007:170). Among the prayers to enter the burial area one of them is:

$$
\text { السلام عليكم دار قوم مؤمنين و إنا إن شاء الله بكم لاحقون }
$$

Meaning: "Salvation for you, the land of the believers. We will follow you on the will of Allah SWT. "

After arriving at the intended tomb then face the face of the dead (facing towards the east) while saying a special greeting, for example:

$$
\text { السلام عليك يا .... (فلان بن فلان/فلانة بنت فلان) أسأل الله لي (ولك/ولك) العافية. }
$$

Meaning: "Safety over you (Fulan). I ask Allah's forgiveness for myself and for you, may Allah forgive my sins and yours. "

After saying greetings read the verses from the Qur'an such as reading the letter of Yasin, Ayat Kursi or reading Tahlil and others. Then proceed by praying. Praying in question does not ask the grave but ask Allah to pray for him and the visiting of graves. In performing the ziarah kubur should be done respectfully and reverently and solemnly ' (calm). Then in the heart, there is a remembrance that one will surely experience death. Then let the pilgrimage not sit on the gravestone of the grave and 
cross on it because it is a painful act of the remains. As Hadith of Amr bin Hazm Al-Anshari:

ر اني رسول الله صلى الله عليه وسلم وأنا متكئ على قبر, فقل : لا تؤذ صاحب القبر. Meaning: Rasulullah SAW had seen me leaning on the grave (tomb), so he said: "Do not hurt those who have a grave." (Subulus Salam 2/120).

Often we see after the funeral of the grave above the tomb sprinkled or laid flowers or wreaths. Or someone at the time to do the ziarah kubur by bringing flowers to put or sprinkled on the tomb.

The laying on of flowers or wreaths above this tomb is really good for the corpse. In the case of flower-mixing on the streets along the way through the bodies, there is no benefit for the corpse.

According to the point of use, it should be cultivated flowers that are not fast wither and dry, then the body will feel the profit. As such in the Hadith of Prophet Muhammad:

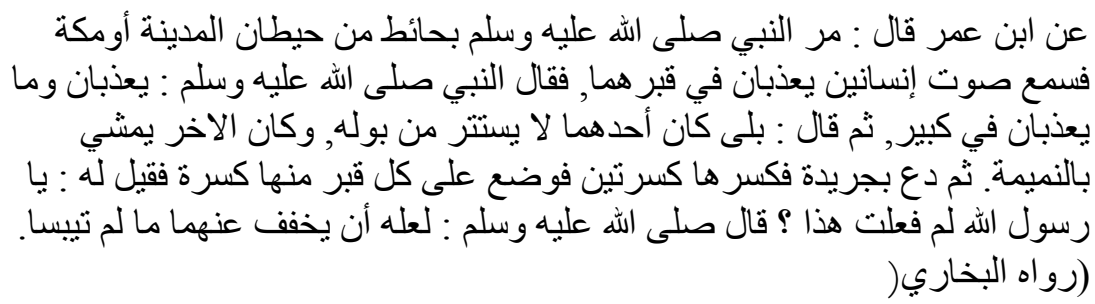

Meaning: From Ibn Umar he said, "Once upon a time the Prophet (PBUH) passed a garden in Makkah or in Medina. Then the Prophet SAW heard the voices of two people who were being tortured in his grave. The Prophet SAW said to his Companions, "The two people (who are in this grave) are being tortured. The two of them were tortured not because they had committed a grave sin. One was tortured for not wearing a covering while urinating. Others were tortured because they often played one another. Rasul SAW then told the Companions to take the palm leaves, then split them into two parts and placed them in each of the graves. The Companions then asked, "Why are you doing this O Rasul?" Rasul SAW replied, "May Allah SWT forgive the two people as long as these two palm fronds are not dry." (Sahih Al-Bukhari, 1273). 
JNUS: Journal of Nahdlatul Ulama Studies, Vol. 1, No. 2, Juli 2020: 131-161

\section{Ziarah Kubur in Ngemplak Kmpulrejo}

The community of Ngemplak Kumpulrejo is known to be quite active in performing grave pilgrimage. It is done because the ziarah kubur is recommended by the Prophet Muhammad SAW because the ziarah kubur contains wisdom and important lessons. Because with someone going and doing the ziarah kubur then it will remind someone of something important, that is the death that a certain time will meet all mankind so that by carrying out the ziarah kubur hopefully one will continue to remember death and avoid excessive love for the glittering pleasures of the world.

Besides, Ngemplak Kumpulrejo people who are well known to have a strong family nature and uphold the attitude of mutual assistance that the grave is like someone who sent something to his family who were in the Pesantren. A person can send provisions to his family who are in the Pesantren using the service of goods or others, but someone will be more satisfied if the provisions are sent themselves because the person can visit and see directly the condition of the person who is in the trend.

Similarly, the community of Ngemplak Kumpulrejo, they prefer to perform the ziarah kubur and pray for the family in the place of the family is buried instead of praying for the deceased family at home. Ziarah kubur is felt more central and beneficial because in addition to praying for the dead they can also introspect themselves and remember the death.

The people of Ngemplak Kumpulrejo on the ziarah kubur on Thursday afternoon before Friday night. The reason why it is performed at this time is to meet the Friday which is Abddurrahaman Ayyam or master of the day. In addition, Javanese people, especially in Ngemplak kgathered, believed that every night of the dead of their families will be in the home of their family. So before the spirits of their deceased families went back to their homes first to visit them in the final resting place of their families.

Another thing that underlies this time-taking is as a condition or routine schedule for the community to routinely carry out grave pilgrimage. The reason for the community Ngemplak Kumpulrejo in 
Ziarah kubur is an important tradition because other than to pray for and remember the spirits of families and their ancestors who have died the ziarah kubur also aims to remind them of death. Besides, from the ziarah kubur procession they do can give a picture of the life done by the inhabitants of the tomb at Ngemplak Kumpulrejo Cemetery and take the Suritauladan from it.

In addition to Thursday evening before Friday, the community of Ngemplak Kumpulrejo also carried out ziarah kubur in Nyadran tradition and 7 days after the death of a person.

Nyadran tradition which means to carry out the ceremony of "Sadran" or "Sadranan" in Ngemplak Kumpulrejo besides done for Besreh or clean the tomb and charity or giving together also performed with the ziarah kubur in people. The ziarah kubur in Nyadran tradition is done to pray for the deceased and as a tribute to the people who struggle both in religious and state affairs in the old days. Nyadran tradition or Kubro pilgrimage is commonly done on Friday Kliwon in the month of Ruwah on Javanese calendar or Syakban in Islamic calendar (Karkono Kamajaya, 1995:246).

\section{The procession of ziarah kubur in Ngemplak Kumpulrejo}

The ordinances or processions of ziarah kuburdone by Ngemplak Kumpulrejo community are as follows:

Uluk salam when entering the cemetery area as the Uluk salam taught in the teaching of Islam.

In addition to Forbearer greetings is recommended by the religion of Islam One of the religious figures in Ngemplak Kumpulrejo that someone who will enter the house of others must be legal to pronounce greetings or kawulonuwun to the home owner. Similarly, when entering the burial area of Uluk Salam was done with the intention to ask permission to the expert graves and forbearer greeting that is pronounced like forbearer greetings taught Islam with the intention that the intent to enter the area of the cemetery is not wrong. 


\section{Besreh or clearing the tomb}

Besreh or clearing the tomb is done with the intention to describe the form of community loyalty to the elders or deceased families. In a grand pilgrimage or commonly called Nyadran tradition by the people of Kemloko cleanse the tomb commonly referred to as Besreh. Besreh the Mass that is commonly done by the people of Kemloko in addition to the purpose of clearing the grave area is to commemorate the memory of each of the burial inhabitants in the cemetery area of his life about how his behavior, his grave condition and how the family is left to the community Kemloko village especially the participants Besreh can introspect himself and always.

\section{Read Tablil}

The community of Ngemplak Kumpulrejo the majority of people who understood Ahlus Sunah Wal Jama'ah often say the prayer of the spirit or Tahlil in praying for the dead is no exception in the ziarah kuburprocession. For Tahlil contains Dzikir, Shalawat and some verses of choice in the Qur'an with the intention that the person who reads the Tahlil get the reward and the reward is given to the deceased by the way of Washilah or intermediary.

\section{Nyekar or sprinkled flowers above the tomb}

Whether it comes from religious teachings or the community is not Ngemplak Kumpulrejo believe that the angels love the smell of fragrance. Thus, during the execution of the pilgrimage they sprinkled flowers above the grave with the intention that the Angels always keep the tomb and hopefully the Angels always pray for the inhabitants of the graveyard sprinkled with flowers. Not clear about the truth of the belief but in the time before the inclusion of Islam to Java, Javanese people already use flowers as offerings. Then after the inclusion of the Islamic religion Walisongo changed the goal so as not to contradict Islamic religion. The flower is used as a refinement of the ziarah kubur procession by 
requesting the Ridha of Allah SWT so that the flower can benefit the grave. This is according to the hadith that explains that in the past when the Prophet Muhammad SAW crossing a tomb he heard the cry from the tomb then he followed one of the Sahaabah to take the wet date and put it to the tomb then he said that when the palm is not dry, Allah SWT will forgive the sin of the people who are in the tomb. Because in Indonesia, especially in Java Island, there is no palm tree, then the palm bark is replaced with flowers. Because with interest in addition to the Suritauladan Prophet Muhammad SAW also as a means of preaching.

\section{Uluk Greetings when will leave the cemetery area}

As for the reason Forbearer greeting when entering the tomb of Forbearer greeting when going to leave the burial area is done but it is recommended by the religion of Islam also aims to farewell to members of the grave to return home. Leaving the burial Area.

\section{Values of Islamic traditions in riarah kubur in Ngemplak Kumpulrejo}

At first the Prophet Muhammad forbade the companions to perform ziarah kubur because at that time he felt the faith level of the companions are weak and feared to happen by worshiping the tomb. But after the Prophet SAW the faith of the friends was strong then he told the companions to perform the ziarah kubur.

Although in the event of ziarah kubur can be done at any time but the community in Ngemplak Kumpulrejo prefer to schedule the timing of the implementation. This is in addition to a tradition that has been passed down in a hereditary manner also in accordance with the teachings of Islam which teaches regularity and discipline in all respects, especially in dividing the time held in one's life.

The implementation of ziarah kubur is Islamic religion, but the Javanese tradition is also contained in it, especially in the procedure of implementation. Some values of Islamic traditions in the implementation of the ziarah kubur in Ngemplak Kumpulrejo are; 1) The value of Islamic traditions contained in Uluk salam when entering and leaving grave Area. 
JNUS: Journal of Nahdlatul Ulama Studies, Vol. 1, No. 2, Juli 2020: 131-161

For greeting that is done in accordance with the teachings of Islam between a believer meet with another believer then ordered to Forbearer Greetings no exception when it will enter and leave the tomb; 2). The value of Islamic traditions in Besreh or the giving of the tomb. Islamic religion teaches hygiene to its people body hygiene, clothing and the environment. Similarly, Besreh tradition aims to clean the burial environment. This is done in addition to a tradition that has been inherited by the ancestors of Besreh also done to keep the burial environment to remain clean and demonstrate good behavior by always keeping the cleanliness of the Muslim; 3) The value of Islamic tradition in Tahlil prayer reading. Although basically in the teachings of Islam carried by the Prophet Muhammad SAW not teach about Tahlil, but the content of Tahlil readings contain Dzikr, Shalawat and some verses of the Qur'an where the three things are recommended to always read and practiced by Muslim; 4) The value of Islamic traditions in the Nyekar or sprinkled flowers on the tomb. Nyekar or sprinkled flowers on top of the tomb is considered thick with the traditions of Javanese people. However, based on a hadith it was once done by the prophet Muhammad SAW when he was on a journey then he heard two people who were being tortured in the grave. Then he told a friend to lay a palm over the two tombs.

\section{The values of Javanese traditions in ziarah kubur in Ngemplak Kumpulrejo}

In the process of implementation, especially in the Ngemplak Kumpulrejo the ziarah kubur usual in a certain time that is on Thursday afternoon before the night of Friday, at the time of the implementation of Nyadran or commonly called Ziarah Kubro.

The thing that underlies these times is as a routine schedule for the burial of ziarah kubur that is intended to preserve the existing traditions that were passed down in generations. In addition, the other reason is as a form of reverence to someone who has died both his family and others who have died against the merits or charity of goodness that has been abandoned by the tomb experts. It is very appropriate to the culture that 
is found in Javanese people who uphold the value of family and mutual respect for each other including those who have died.

The values of Javanese traditions that are found in the ordinances of the Pilgrimage of the grave conducted by the community Ngemplak Kumpulrejo is seen from some of the procession contained therein, namely; 1) The value of Javanese traditions in Uluk salam when entering and leaving the cemetery Area. Javanese people, especially in Ngemplak Kumpulrejo, are known to have good manners. It can be seen from the behavior of those who respect each other. To greet each other when meeting someone known is an example of the attitude of Javanese people, especially in Ngemplak Kumpulrejo. It is also implanted when someone wants to get into a place that is not hers. Similarly, when a person enters the burial area they ask for permission to the owner of the place where in this case the owner of the landlord is the grave member; 2) The value of Javanese traditions in Besreh or tomb clearing. Besreh or clean the tomb in addition to the teaching of Islam is also done in the pilgrimage of Graves or Nyadran by the community Ngemplak Kumpulrejo with the aim to describe the form of public loyalty to the elders of the hamlet and to the family. In addition, Besreh also aims to recall a person in his lifetime as a learning material for those who are still alive; 3) The value of Javanese traditions in the recitation of prayers to the grave members of Tahlil. Among the Javanese community, especially the Ngemplak Kumpulrejo community When performing grave pilgrimage, the prayers that they read are Tahlil prayers. The history of Tahlil prayer is according to some scholars whom the author interviewed are the prayers in which contain Dzikr, Shalawat and some verses of the Qur'an. The Tahlil prayer was practiced by Walisongo who was originally used as a substitute for 7 days, 40, 100 and 100 days which at first the belief came from Hindu teachings in the ceremony of death where the ancestor Spirit (the dead) must be respected because it is believed to be the closest deity of man (https:/ / efriady.wordpress.com/2012/05/26/tradisi-masyarakat-islamyang-bersumber-dari-ajaran-agama-hindu/, accessed on 24 March 2020, 16:54); 4) The value of Javanese traditions in the Nyekar or sprinkled 
JNUS: Journal of Nahdlatul Ulama Studies, Vol. 1, No. 2, Juli 2020: 131-161

flowers on the tomb. In the era of Hindu-Buddhist tradition of Nyekar carried out as a form of none worthy or offerings given to spirits in the grave and the tradition of the Nyekar can still be found in the procession of ziarah kubur performed by Javanese people, especially in Ngemplak Kumpulrejo

Values of Islamic education in the procession of pilgrimage of Javanese people in Ngemplak Kumpulrejo

From the process of the pilgrimage tradition of the graves of Javanese people, especially in Ngemplak Kumpulrejo, district Sidomukti, city of Salatiga besides showing that from the procession of implementation is indeed as Islamic religious teachings also contains the meaning that the Javanese people, especially the community Ngemplak In addition, the Pilgrimage of the grave in Javanese especially in Ngemplak Kumpulrejo also has the educational values contained in it.

The values of Islamic education in the tomb pilgrimage procession are; 1) The value of faith education. By performing ziarah kubur one can remember the death that can be approached. All human beings never know when death will pick them up. By carrying out grave pilgrimages and seeing the grave atmosphere or eating a lonely and visible mound of the graves of people who have died before their eyes, the person will ponder and realize that one time the person would be lucky to be equal to the inhabitants of the tomb that existed before him. The rigid stiffness is helpless and realizes that man will not live forever; 2) The value of education Birrul Walidain. Praying both parents who have passed away is one of the characteristics of a devoted child to both parents. It is also seen in a series of ziarah kubur processions that are commonly implemented by Javanese people, especially in Ngemplak kcollects Rejo. In Besreh tradition or clean the tomb of Javanese people, especially the community Ngemplak Kgather Rejo show loyalty and high love for both parents. In addition they came to the tomb to pray for both parents who have passed away. From these things, it shows that in the tradition of grave pilgrimage, especially in Ngemplak contains important values, namely Qodriyyah 
Walidain or devoted to both parents; 3) The value of education to keep people from being in the world. When someone performs the ziarah kubur it will present the feelings of piety to world and devoted to Allah SWT. At this time many people are captivated by the wiles of the world with all the pleasures it offers. So doing ziarah kubur and remembering that the dead will only return to Allah SWT without carrying any of the treasures and splendor contained in the world then the person who performs the ziarah kubur can take a lesson from it by ever expanding the good charity and leaving the enjoyment offered by the world; 4) Value of social education. In the tradition of grave pilgrimage, especially those found in Ngemplak Kumpulrejo community, there is a value of togetherness and family value that is very strong. It can be seen from a tradition of Besreh or clearing the tomb on the tradition of Nyadran where the people of Ngemplak Kumpulrejo ordinary to implement Besreh tradition together and help each other in the process of implementation.

In addition, in the implementation of the Community Nyadran Ngemplak Kumpulrejo open house or to be welcome to anyone with a guest. Not until there, guests come to be given a wonderful meal. Food and drinks are all served. This indicates that the tradition has good social education and must be preserved in its existence; 5) To take example of Suritauladan In the process of living in this world we must remember that man will not live a long life of this mortal world but man is instructed by God that all mankind will experience death and must prepare all his people to be brought to the next life. Therefore man must prepare a certain death and come the time of death. Every human being who lives will suffer death. Only charity is good deeds that will take people to face Allah SWT with faith and charity as a good form of human and noble morality.

\section{CONCLUSION}

Based on the results of the research above, the authors conclude the results of the study that the values of Islamic education in the tradition of ziarah kubur of Javanese people in Ngemplak Kumpulrejo, Sidomukti, Salatiga as follows; 1) History of ziarah kubur in Islamic religious 
teachings. Ziarah kubur is part of the ritual of Islamic religion. In the early days of Islam, the Prophet Muhammad SAW once banned his people to perform ziarah kubur because he was worried about the occurrence and adoration of the Karana cemetery at that time the faith level of Muslim is still weak. But after the prophet Muhammad SAW felt the faith level of Muslims are strong he finally allowed Muslims to carry out the ziarah kubur with the intention that Muslims always remember the death that a certain time will find all human beings so that people can introspect and avoid excessive love for the enjoyment of the world; 2) Ritual or ordinances that are found in the ziarah kubur in Ngemplak Kumpulrejo. The people of Ngemplak Kumpulrejo have performed a ziarah kubur with several ordinances in it. Beginning with the pronunciation of the greeting when entering the funeral area, then after arriving at the intended tomb they will clean the tomb or better known as Besreh, then followed by reading a prayer that is addressed to himself and also the grave member with the recitation of Tahlil prayer, followed by the last ritual by sprinkled flowers or Nyekar on the ziarah kubur. Then after the procession of the tomb pilgrimage completed they left the burial area by giving an Uluk salam. From the rituals or ordinances they all contain values taught by Islam as well as values of Javanese traditions. In the procession of pilgrimage to the grave conducted by the community Ngemplak Kumpulrejo there are 2 different elements, namely the teachings of Islam and Javanese traditions that are united in a traditional procession that is found in the life of Javanese people, especially in Ngemplak Kumpulrejo. The tradition is named Ziarah kubur tradition. In the implementation it can be seen clearly that both elements can be unified and walk coincide without eliminating the important values of both elements; 3) The values of Javanese Islamic education which is in the procession of pilgrimage in Javanese community, especially in Ngemplak Kumpulrejo. In the process of the pilgrimage tradition of the graves of Javanese people, especially the community Ngemplak Kumpulrejo, Sidomukti, Salatiga contains educational values in it. From the educational values contained in the pilgrimage tradition of the grave is the value of education of the faith, the 
value of education of Qodriyyah Walidain, the value of education so that people always have to do to the world and the value of social education. And then is expected to be taken from the procession of ziarah kubur tradition.

\section{BIBLIOGRAPHY}

Abdul, Fattah., Munawar. 2008. Tradisi Orang-orang NU. Yogyakarta: Lkis Pusaka Pesantren.

Amin, Darori. 2002. Islam dan Kebudayaan Jawa. Yogyakarta: Gama Medi. Amsyari., Fuda. 1993. Masa Depan Umat Islam Indonesia. Bandung: AlBayan.

Book Compilation Team of Jumenengan Sri Sultan Hamengku Buwono X. 1995. Upacara Tradisional Jumenengan, Arti, Fungsi dan Makna Lambang. Yogyakarta: Restu Prima Grafika.

Bungin, Burhan. 2012. Analisis Data Penelitian Kualitatif. Jakarta: Rajawali Pers.

Chanafi, M. Afnan. \& Asrori. 2007. Tradisi Islam Panduan Prosesi Kelabiran, Perkawinan, Kematian). Surabaya: Khalista.

Chudlori, M. Yusuf. 2007. Menapak Hidup Baru (Doa-doa Keseharian ArabLatin dan Terjemahnya. Surabaya: Khalista.

Department of Education and Culture Prov. Central Java. 2007. Peninggalan Masa Islam di JawaTengah Abad XV-XVIII M. Semarang: Museum Jawa Tengah Ronggowarsito.

Gazalba, Sidi \& Madya. 1988. Islam dan Kesenian Relevansi Islam Dengan SeniBudaya Karya Manusia). Jakarta: Pustaka Alhusna.

Gazalba, Sidi. 1976. Masyarakat Islam: Pengantar Sosiologi dan Sosiografis. Jakarta: Bulan Bintang.

Hadi, Saputro. Budiono. 2010. Sejarah Wali Songo (Misi Pengislaman di Jawa). Yogyakarta: Graha Pustaka.

Humaedi, M. Alie. 2008. Islam dan Kristen di Pedesaan Jawa: Kajian Konflik Sosial Keagamaan dan Ekonomi Politik di Kasimpar dan Karangkobar. Badan Litbang dan Diklat Departemen Agama RI.

Hasan, Fuad. 2003. Dasar-dasar Kependidikan. Jakarta: PT. Asdi Mahasatya 
JNUS: Journal of Nahdlatul Ulama Studies, Vol. 1, No. 2, Juli 2020: 131-161

http://blogganeh.blogspot.com/2013/08/materi-sejarah-kelas-xi-

masuknya.html, accessed on November $\left.10^{\text {th }} 2014,19.02\right)$.

http:/ /www.fimadani.com/hukum-ziarah-kubur-adab-adab-dan-

larangannya/, accessed on November $\left.20^{\text {th }} 2014,12.56\right)$.

https://efriady.wordpress.com/2012/05/26/tradisi-masyarakat-islam-

yang-bersumber-dari-ajaran-agama-hindu/, accessed on January $13^{\text {th }}$ 2015, 16:54).

Indonesian Dictionary Compilation Team, 1989. Kamus Besar Bahasa

Indonesia. Jakarta: Balai Pustaka.

Indonesian Old Javanese Dictionary Compilation Team. 2006. Kamus Jawa

Kuna Indonesia. Jakarta: Gramedia Pustaka Utama.

Kamajaya, Partokusumo. Karkono. 1995. Kebudayaan Jawa, Perpaduannya dengan Islam. Yogyakarta: Aditya Media.

Kartono, Kartini. 1992. Pengantar Ilmu Mendidik Teoritis. Bandung: Mandar Maju

Khalil, Ahmad. 2008. Islam Jawa: Sufisme dalam Etika dan Tradisi Islam. Malang: UIN-Malang Press.

Koentjaraningrat. 1994. Kebudayaan Jawa. Jakarta: Balai Pustaka.

Koentjaraningrat. 1984. Kebudayaan Mentalitas dan Pembangunan. Jakarta: PT.

Gramedia.

Kutha, Rasta. Nyoman, 2010. Metodologi Penelitian. Yogyakarta: Pustaka Pelajar.

Majid, Cholish. Nur. 1997. Tradisi Islam: Peran dan Fungsinya dalam Pembangunan di Indonesia. Jakarta: Paramadina.

Maman, Abdul. 2006. Keagungan Rajab \& Sya’ban. Jakarta: Republika.

Mansur. 2004. Peradaban Islam Dalam Lintas Sejarah. Yogyakarta: Global Pustaka Utama.

Moeloeng, J. Lexy. 2009. Metodologi Penelitian Kualitatif. Bandung: PT Remaja Rosdakarya.

Muljana, Slamet. 2007. Runtubnya Kerajaan Hindu-Jawa dan Timbulnya Negara-Negara Islam di Nusantara. Yogyakarta: LkiS Yogyakarta.

Ngajena, Mohamad. 1990. Kamus Etimologi Bahasa Indonesia. Semarang: Daharia Prize. 
Islamic Education Values in Ziarah Kubur Tradition ..... (Matrokhim)

Noer, Kautsar. Azhari. 2005. Pluralisme, Konflik dan Pendidikan Agama di Indonesia. Yogyakarta: Pustaka Pelajar.

Notowidagdo, Rohiman. 2002. Ilmu Budaya Dasar Berdasarkan Al-Qur'an. Jakarta: Raja Grafindo Persada.

Purwadi. 2005. Ensiklopedia Kebudayaan Jawa. Yogyakarta: Dina Media.

Ruslan, Rosady, 2010. Metode Penelitian: Public Relations dan Komunikasi. Jakarta: Rajawali Pers.

Saksono, Widji. 1995. Mengislamkan Tanah Jawa (Telaah Atas Metode Dakwah Walisongo). Bandung: Mizan.

Simuh. 1996. Sufisme Jawa, Transformasi Tasawuf Islam ke Mistik Jawa. Yogyakarta: Yayasan Bintang Budaya.

Steenbrink, A. Karel. 1984. Beberapa Aspek Tentang Islam di Indonesia Abad ke-19. Jakarta: Bulan Bintang.

Suprayogo, Imam \& Tobroni. 2001. Metodologi Penelitian Sosial Agama. Bandung: Remaja Rosdakarya. 